Bulgarian Academy of Sciences. Space Research and Technology Institute. Aerospace Research in Bulgaria. 30, 2018, Sofia

DOI: https://doi.org/10.3897/arb.v30.e02

\title{
STUDY OF WASTE DISPOSAL THERMAL RADIATION USING SATELLITE DATA AND CONSIDERING SOLAR INFLUENCE
}

\author{
Adlin Dancheva, Simeon Asenovski \\ Space Research and Technology Institute - Bulgarian Academy of Sciences \\ e-mail: adlin.dancheva@space.bas.bg; asenovski@space.bas.bg
}

\begin{abstract}
In the present article distribution of the waste disposal thermal radiation caused by biochemical processes of decomposition is examined. Using thermal channels of the Landsat 8 (OLI) the waste disposal spectral characteristics are obtained. All this data is compared with solar activity during the same period and differences between internal thermal radiation and solar influences are discussed.
\end{abstract}

\section{Introduction}

With the permanent increasing of human population, a serious problem concerning air and water pollution and also soil contamination arises. This is the problem of waste disposals sites (WDS) and its influence on the surrounding environment $[1,2]$. These disposals are main source of methane emissions $\left(\mathrm{CH}_{4}\right)$, which is one of the greenhouse gases with strong influence on the atmosphere and prerequisite of the greenhouse effect with anthropogenic character. Waste gases are organic products, a result from decomposition of waste in anaerobic conditions. They are composed mainly from methane $\left(\mathrm{CH}_{4}\right)$ and carbon dioxide $\left(\mathrm{CO}_{2}\right)[3,4]$.

The areas occupied by waste disposals are rapidly growing, as in some cases they are unregulated. For example in 2012, $481 \mathrm{~kg}$ solid waste per single person for the population in European Union is generated [5].

This research focuses on Suhodol waste disposal close to the Bulgarian capital, Sofia. Officially this disposal was formed 30 years ago with purpose of Sofia municipality waste collecting. Its exploitation is achieved in two stages, and the first stage was until 1995.

The main goal of this work is calculating the surface temperature caused by waste internal thermal radiation and determining the places where the temperature is the highest (thermal points). Several time intervals are examined. 
In Fig. 1 is shown the location of the waste disposal Suhodol, Sofia. The object is in geographic coordinates $23^{\circ} 12^{\prime} 03^{\prime \prime} \mathrm{E}$ and $42^{\circ} 41^{\prime} 26^{\prime \prime} \mathrm{N}$ (WGS 84, UTM $34 \mathrm{~N})$.

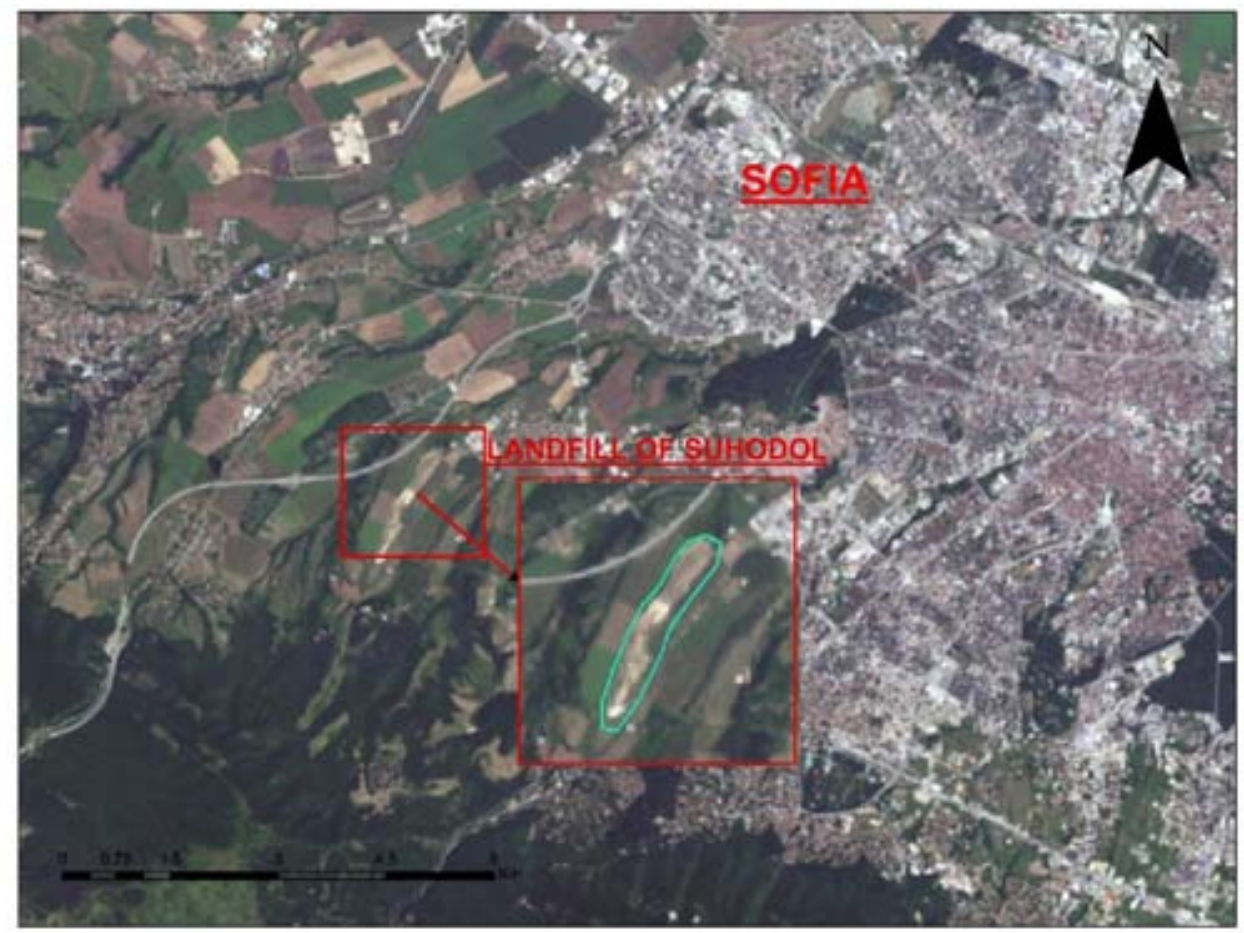

Fig. 1. Location of the waste disposal Suhodol, Sofia.

\section{Materials and methods}

Current investigation uses thermal channels of Landsat 5-7 ETM+ and Landsat $8 \mathrm{OLI} / \mathrm{TIRS}$, as for the calculation of thermal radiation is used band 6 of Landsat ETM+ with wave length $10.40 \div 12.50 \mu \mathrm{m}$ and band 10 with wave length $10.6 \div 11.9 \mu \mathrm{m}$. Images for four years and for two different seasons (winter and summer) are considered. In Table 1 are described the images.

We can write a general formula for Landsat 4-8: [6-9]

$$
\mathrm{T}_{[K]}=\mathrm{a} * \ln ^{-1}\left(\frac{b}{c * Q+d}+1\right)
$$

Where $a, b, c$, and $d$ are the constants for the different types of Landsat images, $T$ is the pixel temperature $(\mathrm{K}), Q$ is the spectral brightness coefficient of the 
surface in the thermal channel Landsat (4-8) satellite images are downloaded from web page https://earthexplorer.usgs.gov/.

Table 1. Used Landsat satellite images

\begin{tabular}{|l|l|}
\hline Date & \multicolumn{1}{|c|}{ Satellite } \\
\hline 31.01 .2004 & Landsat 7 ETM+ \\
\hline 18.08 .2004 & Landsat 5 TM \\
\hline 28.01 .2006 & Landsat 5 TM \\
\hline 23.07 .2006 & Landsat 5 TM \\
\hline 02.01 .2009 & Landsat 5 TM \\
\hline 23.07 .2009 & Landsat 7 ETM+ \\
\hline 02.01 .2017 & Landsat 7 ETM+ \\
\hline 21.07 .2017 & Landsat 8 OLI \\
\hline
\end{tabular}

After the georeferencing procedure of the thermal images the cutting out of the rectangular sections in each image covering the vicinity of the geographic coordinates is carried out. The time series $\{\mathrm{Q} 1, \mathrm{Q} 2, \ldots, \mathrm{Qn}\}$ of the images in the thermal channel of each WDS are extracted. The data from the image is converted into the surface temperature $\{\mathrm{T} 1, \mathrm{~T} 2, \ldots, \mathrm{Tn}\}$ using transformation:

$$
\mathrm{T}_{\left[C^{0}\right]}=\mathrm{a} * \operatorname{Ln}^{-1}\left(\frac{b}{c * Q+d}+1\right)-273.15
$$

where:

$a$ is the $K_{2}=$ Thermal conversion constant for the band (K2_CONSTANT_BAND_n from the metadata);

$b$ is $K_{1}=$ Thermal conversion constant for the band (K1_CONSTANT_BAND_n from the metadata);

$c$ is $M_{l}=$ Radiance multiplicative scaling factor for the band (RADIANCE_MULT_BAND_n from the metadata);

$d$ is $L_{\chi}=$ Spectral radiance $(\bar{W} /(m 2 * s r * \mu m))$;

$\mathrm{Q}=\mathrm{L} 1$ pixel value in $\mathrm{DN}$;

$\mathrm{T}=\mathrm{TOA}$ ( Top of Atmosphere) Brightness Temperature

The time series for WDS are formed together with the mask for clouds and "blankness" and are entered into the database. The time series of images for temperature for each landfill or WDS is systematized [10]. 


\section{Results}

Presented results are for the following days: 18.08.2004, 31.01.2004, 23.07.2006, 28.01.2006, 23.07.2009, 02.01.2009, 02.01.2017 and 21.07.2017. We have tracked the internal thermal radiation of the Suhodol waste disposal for four different years. In Fig. 2 land surface temperature (LST) of waste disposal Suhodol is presented. Hot spots are situated in the center of the landfills. A temperature variation of $4^{\circ} \mathrm{C}$ between the center and surrounding area is observed. Average surface temperature is $-7^{\circ} \mathrm{C}$ while the core temperature of the landfills reaches $-4^{\circ} \mathrm{C}$.

In Fig 3 the temperature for 18.08.2004 is calculated. In the summer there is an increased rotting activity which increases the temperature of this area. Hot spots move beyond the limits of the landfill. The average surface temperature is $+26^{\circ} \mathrm{C}$ while the temperature within the landfill reaches $+31^{\circ} \mathrm{C}$.

During the winter of 2006 the average surface temperature is $-6^{\circ} \mathrm{C}$, and within the landfill it reaches $-4^{\circ} \mathrm{C}$. The hot spots move toward the center and the north parts of the observed object (Fig. 4).

In 23.07.2006 the same temperature displacement as in July 2004 is detected. The highest temperature is again at the center of the object in question as well as in its north part $\left(+34^{\circ} \mathrm{C}\right)$.

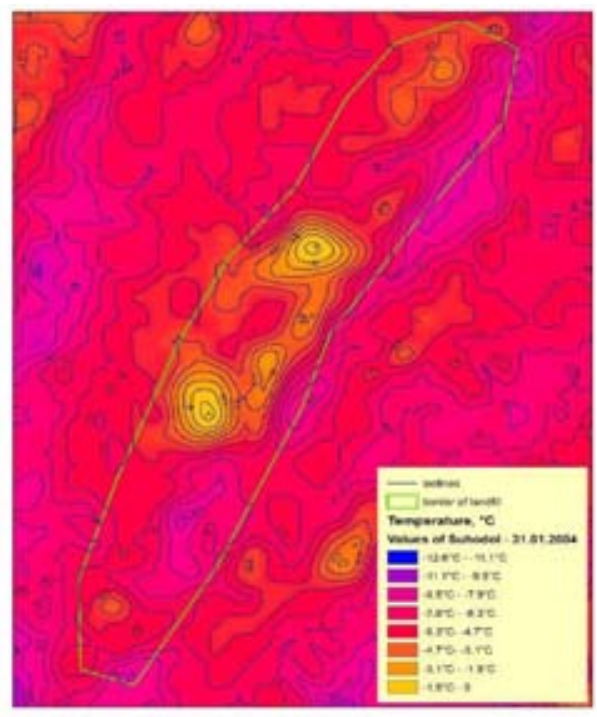

Fig. 2. LST of Suhodol - 31.01.2004

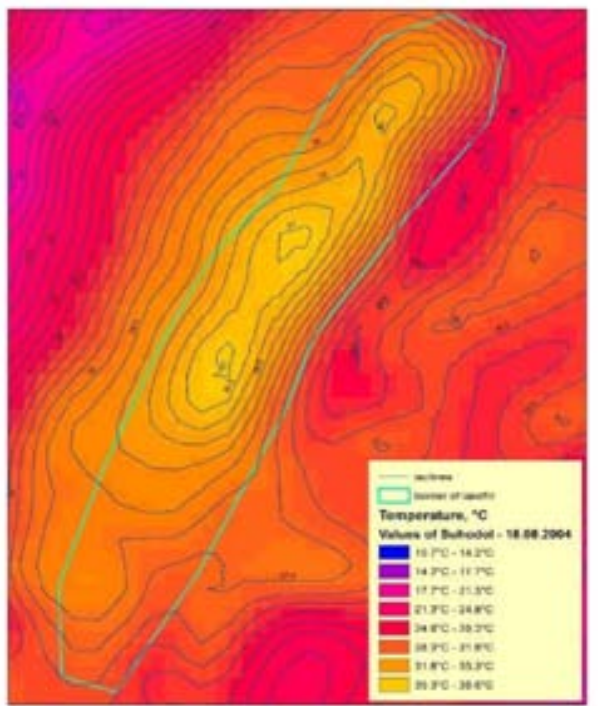

Fig. 3. LST of Suhodol - 18.08.2004 


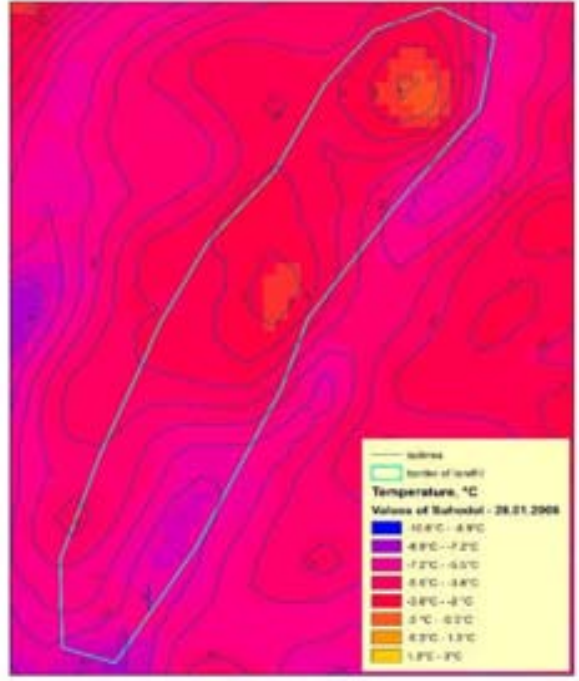

Fig. 4. LST of Suhodol-28.01.2006

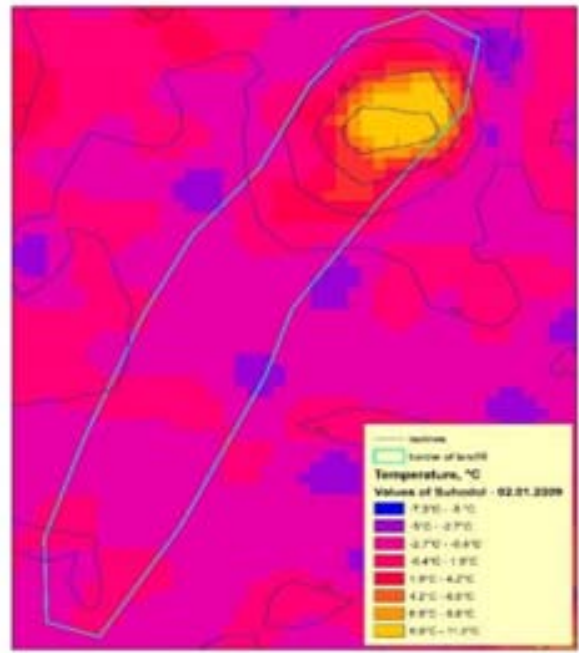

Fig. 6. LST of Suhodol-02.01.2009

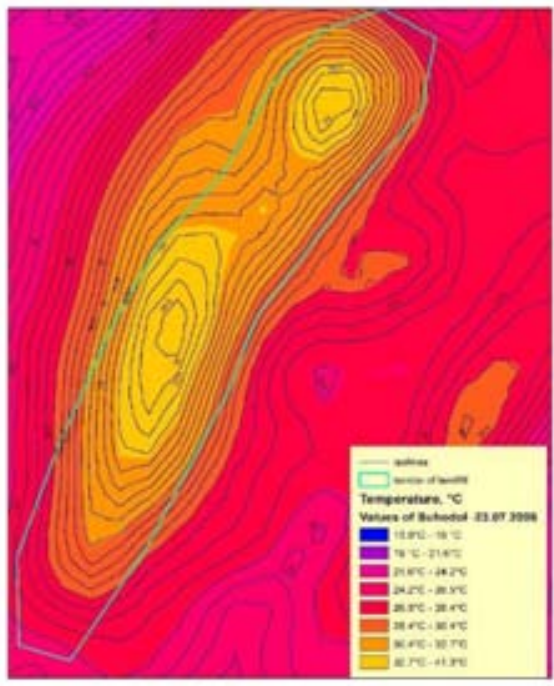

Fig. 5. LST of Suhodol-23.07.2006

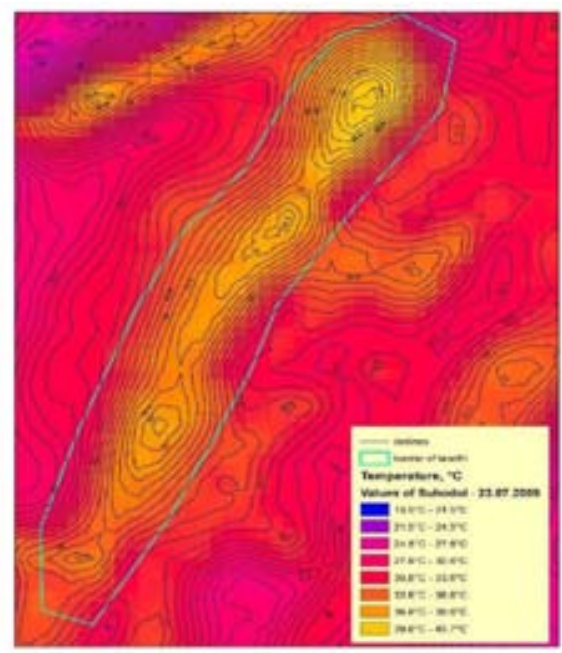

Fig. 7. LST of Suhodol-23.07.2009 


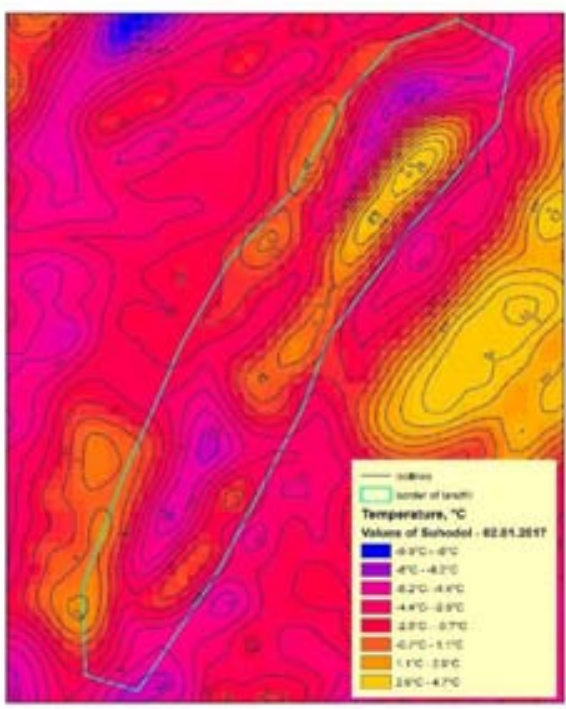

Fig. 8. LST of Suhodol-02.01.2017

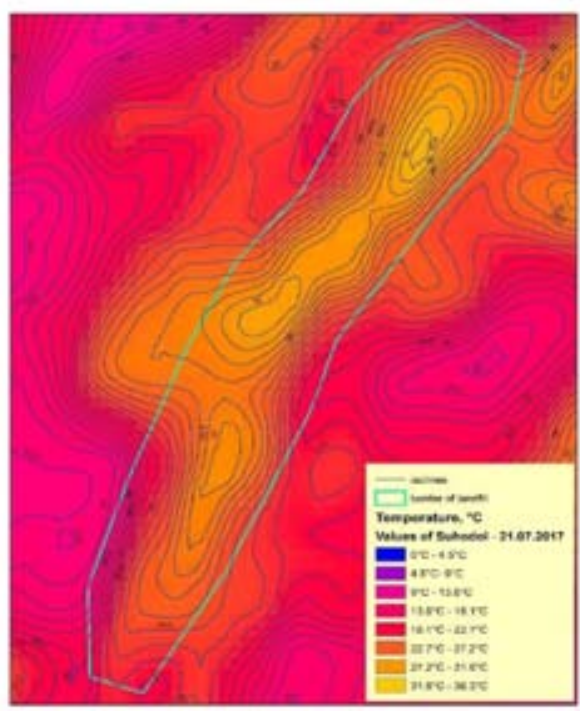

Fig. 9. LST of Suhodol-21.07.2017

In Fig. 6 is shown that the hot spots are entirely in the northern part of the investigated object. The average surface temperature is $-0.5^{\circ} \mathrm{C}$, while within the landfill it is $+1^{\circ} \mathrm{C}$. In the end of the July 2009 (Fig. 7) a major change in landfill temperature is observed. The highest values are found in the northern part $-+38.5^{\circ} \mathrm{C}$. The average temperature is $+29^{\circ} \mathrm{C}$.

In January 2017 significant displacement of the hotspot compared to previous years is observed. The temperature difference between the object and surrounding area is $2^{\circ} \mathrm{C}$. In Fig. 8 are presented calculated temperature values for 21.07.2017. The temperature has the highest values in the northern part of the landfill $+33^{\circ} \mathrm{C}$.

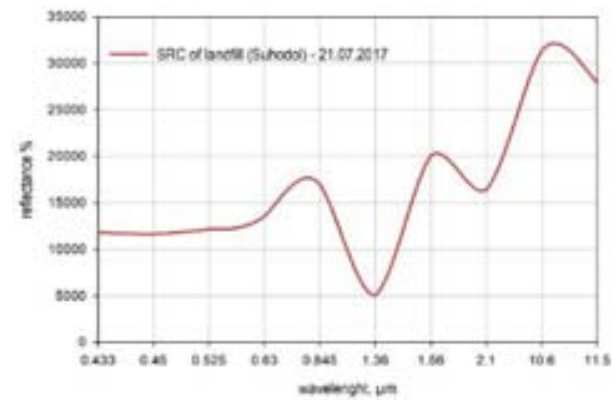

Fig. 10. Spectral reflectanse characteristics of landfill

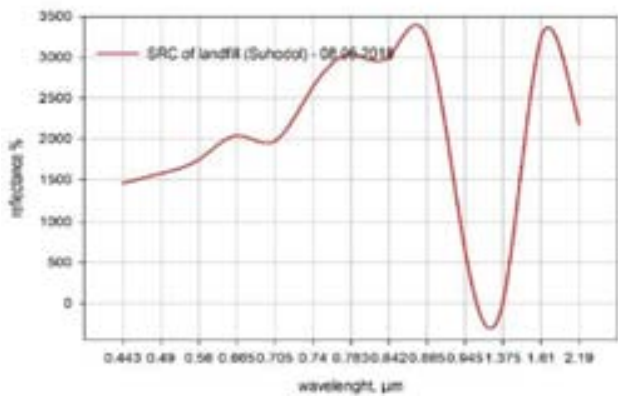

Fig.11. Spectral reflectanse characteristics of lanfill 
For comparison, landfill spectral characteristic with different sensors are made. In Fig. 10 and 11 spectral reflective characteristics of the waste disposal Suhodol for 21.07.2017 and 08.06.2018 are presented. The used sensors are Landsat 8 and Sentinel 2 (Copernicus, ESA, https://scihub.copernicus.eu).

\section{Solar activity}

Land surface temperature (LST) is one of the most usable parameters in studying the physical and chemical processes and phenomena that involve energy balance in hydrology, biology meteorology etc. Short and long-term variation of LST depends strongly on the amount the solar energy that reaches the Earth's surface and therefore on the diurnal variation, seasons and climate zones. One of the most reliable indicators for the estimation of the solar energy that reaches the Earth is solar irradiance $\left(\mathrm{W} / \mathrm{m}^{2}\right)$ and the solar f10.7 index $(2800 \mathrm{MHz})$ which correlates with the sunspot number and Ultra Violet (UV) radiation. F10.7 radio emissions are very sensitive to the processes in the upper chromosphere and at the base of the solar corona. It is present in solar flux units (sfu), where $1 \mathrm{sfu}=10^{-22} \mathrm{~W} \mathrm{~m}^{-2} \mathrm{~Hz}^{-1}$.

In Fig. 12 and Fig. 13 are shown the variations of the total solar irradiance (W.m ${ }^{-2}$ ) (http://spot.colorado.edu/ koppg/TSI/) for the last several years that reach the outer part of the Earth's atmosphere and solar radio index $10.7 \mathrm{~cm}$ (sfu) (https://omniweb.gsfc.nasa.gov). It can be seen that during the period of last solar minimum, i.e. 2016-2018, the values of both indicators are smaller than those measured in previous years.

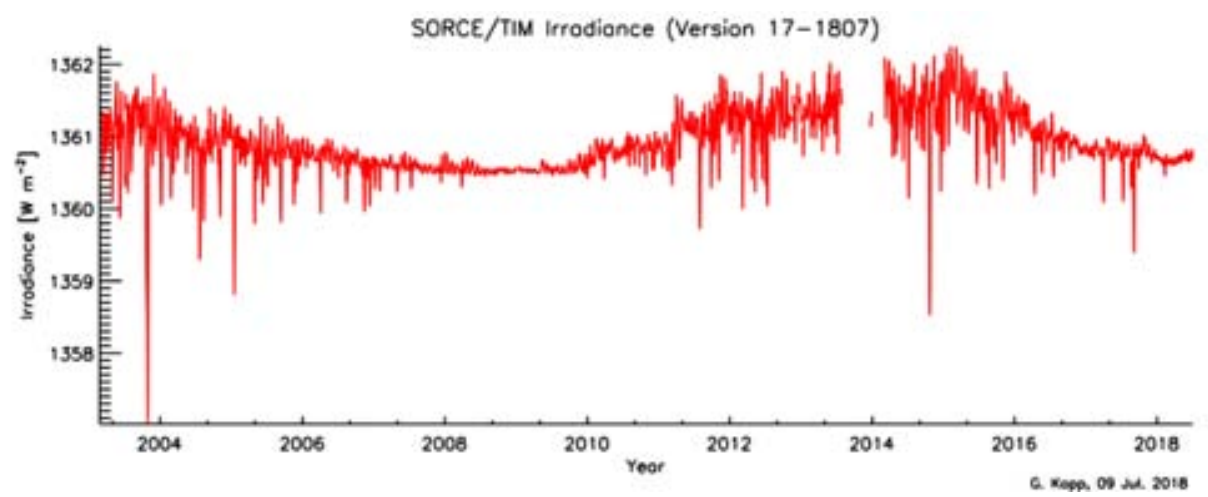

Fig. 12. Variation of the total solar irradiance 


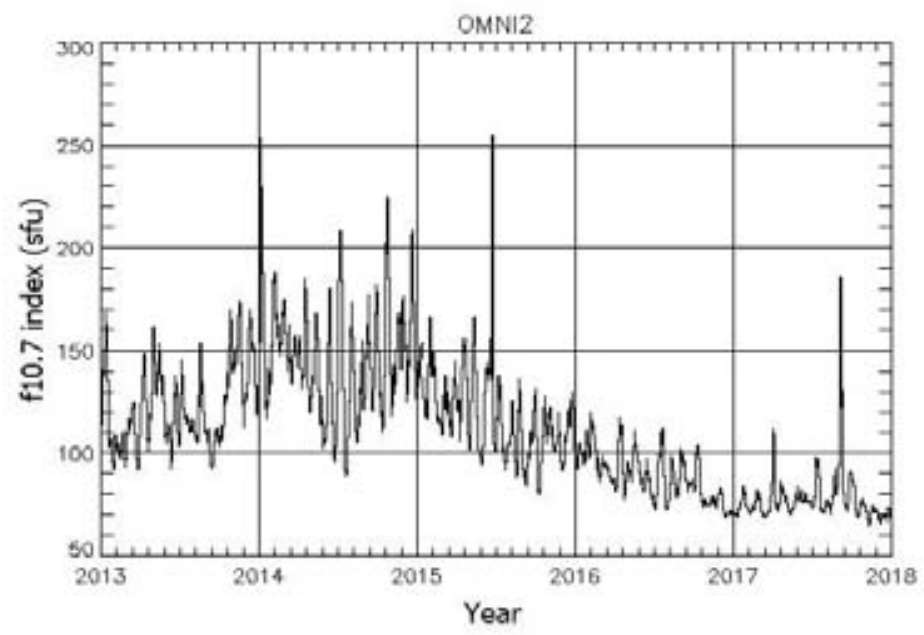

Fig. 13. Variation of the solar radio flux at $10.7 \mathrm{~cm}$

\section{Conclusion}

This work presents a study of Suhodol waste disposal and its thermal radiation caused by biochemical processes of decomposition using satellite data. The results can be summarized in the following statements:

- In 18.08.2004 an increased rotting activity is observed which increases the temperature of the landfill. Hot spots move beyond the limits of the landfill.

- During the winter of 2006 the hot spots move toward the center and northern parts of the observed object.

- In 23.07.2006 the same temperature displacement as in July 2004 is detected. The highest temperature is again at the center of the object in question as well as in its north part $\left(+34^{\circ} \mathrm{C}\right)$.

- In January 2009 the hot spots are entirely in the northern part of the investigated object while in the end of the July 2009 a major change in landfill temperature is observed.

- In January 2017 significant displacement of the hotspot compared to previous years is observed. The temperature difference between the object and surrounding area is $2^{\circ} \mathrm{C}$. The temperature has the highest values in the northern part of the landfill $-+33^{\circ} \mathrm{C}$.

- According to the F10.7 index and Solar irradiance, solar energy reaching the surface during the period of last solar minimum - 2016-2018, is less than the measured in previous years. The observed landfill temperature variation do not show measurable dependence with solar activity. 


\section{References}

1. Казарян, М. Л., А. А. Рихтер, М. А. Шахраманьян, Р. Недков. Космический мониторинг объектов захоронения твердых бытовых отходов и промышленных отходов (тбо и по): теоретико-методические и социальноэкономические аспекты. М.: Научная мысль, ИНФРА-М, 2018, ISBN:978-5-16014435-1 (print), 978-5-16-106965-3 (online), DOI: dx.doi.org/10.12737

2. Nedkov, R., M. Dimitrova, M. Zaharinova, and I. Ivanova. Web monitoring of fires on Balkans based on satellite data during July and August 2007. Ecological Engineering and Environment Protection, 2008, 1, 13-19. ISSN 1311-8668

3. Shakhramanyan, M., Richter, A., Kazaryan, M., Nedkov, R., Borisova, D., Stankova, N., Ivanova, I., Zaharinova, M. Evaluation of chemical process parameters in waste disposal sites by satellite images. Ecological Engineering and Environment Protection, 2017, 1, 22-28. ISSN 1311-8668

4. Ganev, I., A. Tcanova, Neotralization and oxidation of landfill gas, Energy forum 2006, https://inis.iaea.org/collection/NCLCollectionStore/_Public/38/105/38105235.pdf

5. EEA, Resource efficiency and waste, https://www.eea.europa.eu/bg/signals/signali2014-g/statii/otpadatsite-problem-ili-resurs

6. Richter, A., M. Kazaryan, M. Shakhramanyan, R. Nedkov, D. Borisova, N. Stankova, I. Ivanova, and M. Zaharinova, Estimation of thermal characteristics of Waste disposal sites using Landsat satellite images. Comptes rendus de l'Academie bulgare des Sciences, 2017, 70, 2.

7. Nedkov, R. Quantitative assessment of forest degradation after fire using ortogonalized satellite images from Sentinel-2. Comptes rendus de l'Academie bulgare des Sciences, 2018, 71, 1, 83-86. ISSN 2367-5535

8. Richter, A., M. Kazaryan, M. Shakhramanyan, R. Nedkov, D. Borisova, N. Stankova, I. Ivanova, and M. Zaharinova. Quality enhancement of satellite images and its application for identification of surroundings of waste disposal sites. Proc. SPIE $10444,5^{\text {th }}$ International Conference on Remote Sensing and Geoinformation of the Environment (RSCy2017), 10444, SPIE, 2017. DOI:10.1117/12.2277309

9. Landsat 8 Data Users Handbook. 2016, v. 2. USGS, https://landsat.usgs.gov/sites/default/ files/documents/Landsat8DataUsersHandbook.pdf

10. Kuenzer, C. et al. Spaceborne thermal infrared observation - an overview of most frequently used sensors for applied research, in: Kuenzer, C. and S., Dech, (eds) Thermal Infrared Remote Sensing SE-7. Springer Netherlands (Remote Sensing and Digital Image Processing), 131-148. DOI:10.1007/978-94-007-6639-6_7.

11. Fjelsted, L., et al. Assessment of a landfill methane emission screening method using an unmanned aerial vehicle mounted thermal infrared camera - A field study. Waste Management and Research, 2018, DOI:10.1016/j.wasman.2018.05.031

12. Iacoboaea, C., F. Petrescu, Landfill monitoring using remote sensing: a case study of Glina, Romania, Waste Management and Research, 2013, 31, 10, 1075-80, DOI: $10.1177 / 0734242 X 13487585$

13. Windahl, E., K. Beurs, An intercomparison of Landsat land surface temperature retrieval methods under variable atmospheric conditions using in situ skin temperature, International Journal of Applied Earth Observation and Geoinformation, 2016, 51, 11-27, DOI:10.1016/j.jag.2016.04.003 


\title{
ИЗПОЛЗВАНЕ НА СПЪТНИКОВИ ДАННИ ЗА ИЗСЛЕДВАНЕ НА СОБСТВЕНОТО ТОПЛИННО ИЗЛЪЧВАНЕ НА СМЕТИЩА С ОТЧИТАНЕ НА ВЛИЯНИЕТО НА СЛЬНЦЕТО
}

\author{
А. Данчева, С. Асеновски
}

\section{Резюме}

В настоящата работа се изследва разпределението на собственото топлинно излъчване на сметища, предизвикано от биохимични процеси на разлагане. Използвани са топлинните канали на сензора Landsat 8 (OLI). Получени са спектрални характеристики на сметища от сензорите Landsat 8 и Sentinel 2. На базата на спътникови данни за слънчевата активност са отчетени разликите между собственото топлинно излъчване и влиянието на Слънцето. Получени са резултати за различни времеви сезони от различни по своето пространствено разпределение сметища. 